\title{
Pandemic (H1N1) 2009 Influenza
} Virus Infection in A Survivor Who Has Recovered from Severe H7N9 Virus Infection, China

\author{
Shan-Hui Chen ${ }^{1 \dagger}$, Meng-Na Wu2t, Yan-Hua Qian't, Guang-Yuan Ma1', Guo-Lin Wang ${ }^{2}$, \\ Yang Yang ${ }^{3}$, Teng Zhao ${ }^{2}$, Bing $\mathrm{Lu}^{1}$, Mai-Juan $\mathrm{Ma}^{2 *}$ and Wu-Chun $\mathrm{Cao}^{2 *}$
}

${ }^{1}$ Wuxi Center for Disease Control and Prevention, Wuxi, China, ${ }^{2}$ State Key Laboratory of Pathogen and Biosecurity, Beijing Institute of Microbiology and Epidemiology, Beijing, China, ${ }^{3}$ Department of Biostatistics, University of Florida, Gainesville, FL, USA

\section{OPEN ACCESS}

Edited by:

Tao Dong,

University of Oxford, UK

Reviewed by:

Linghang Wang,

Beijing Ditan Hospital, China

Peng Yang,

Beijing Center for Disease Prevention and Control, China

${ }^{*}$ Correspondence:

Mai-Juan Ma mjma@163.com

Wu-Chun Cao

caowc@bmi.ac.cn

†These authors have contributed equally to this work.

Specialty section:

This article was submitted to Infectious Diseases,

a section of the journal

Frontiers in Microbiology

Received: 16 July 2016 Accepted: 09 September 2016 Published: 04 October 2016

Citation:

Chen S-H, Wu M-N, Qian Y-H, Ma G-Y, Wang G-L, Yang Y, Zhao T, Lu B, Ma M-J and Cao W-C (2016)

Pandemic (H1N1) 2009 Influenza Virus Infection in A Survivor Who Has Recovered from Severe H7N9 Virus Infection, China.

Front. Microbiol. 7:1514 doi: 10.3389/fmicb.2016.01514
We firstly report a patient who presented with severe complications after infection with influenza $\mathrm{A}(\mathrm{H} 1 \mathrm{~N} 1)$ pdm2009, more than 1 year after recovery from severe $\mathrm{H} 7 \mathrm{~N} 9$ virus infections. The population of patients who recovered from severe H7N9 infections might be at a higher risk to suffer severe complications after seasonal influenza infections, and they should be included in the high-risk populations recommended to receive seasonal influenza vaccination.

Keywords: pdm09 (H1N1) virus, H7N9 virus, subsequent infection, serological detection, vaccination

\section{BACKGROUND}

Since the emergence of human infections with avian influenza A (H7N9) virus in February 2013, China has experienced four epidemic waves of this virus. Due to its co-circulation with influenza A (H1N1) pdm09 (pH1N1), seasonal influenza A (H3N2 and H1N1), and influenza B viruses in China, human co-infections with the avian H7N9 virus and these human influenza viruses have been reported (Zhu et al., 2013; Li et al., 2014; Zhang et al., 2015). Most H7N9 patients had severe symptoms during hospitalization and their pulmonary functions were seriously damaged, which might have increased their susceptibility to subsequent viral infections including human seasonal influenza viruses after their recovery from the H7N9 infection. Here, we report a case of pH1N1 virus infection who had survived from H7N9 infection about 1 year and 3 months ago.

\section{CASE REPORT}

On April 20, 2014, a 66-year-old retired man, who had a history of hypertension for over 20 years, presented influenza-like-illness (ILI) symptoms with fever $\left(38^{\circ} \mathrm{C}\right)$, cough, and expectoration sputum. According to the epidemiological investigation, 5 days before symptoms presentation the patient visited a local live poultry market and purchased one pigeon. On April 25, he sought medical care at community clinic when his symptoms were getting worse, where he was diagnosed of left lower lobe pneumonia. Because of his severe conditions, he was transferred to the respiratory department of a city level hospital on the same day and was diagnosed of left pneumonia and chronic bronchitis. The admission assessment of vital signs revealed a temperature of $39^{\circ} \mathrm{C}$, a pulse of 101 beats per minute, a blood pressure of $130 / 80 \mathrm{mmHg}$, a respirations rate of 22 breaths per minute, a saturation of peripheral oxygen ( $\mathrm{SpO} 2)$ of $99.4 \%$, a pressures of oxygen 
TABLE 1 | Clinical characteristics of patient with confirmed H7N9 and pH1N1 infection on hospital admission.

\begin{tabular}{|c|c|c|}
\hline Characteristic & H7N9 infection & pH1N1 infection \\
\hline Age (years) & 66 & \\
\hline Sex & Male & \\
\hline Occupation & Retired & \\
\hline Type of exposure & $\begin{array}{l}\text { Visited live poultry } \\
\text { market and } \\
\text { purchased one } \\
\text { pigeon }\end{array}$ & $\mathrm{n} / \mathrm{a}$ \\
\hline Underlying medical disorders & Hypertension & Hypertension \\
\hline Smoking & Yes & No \\
\hline Influenza vaccination & No & No \\
\hline Onset of illness & 20 April 2014 & 25 December 2015 \\
\hline Date of hospital admission & 25 April 2014 & 27 December 2015 \\
\hline Date of hospital discharge & 22 August 2014 & 4 January 2016 \\
\hline Signs of illness & $\begin{array}{l}\text { Fever, cough, and } \\
\text { expectoration } \\
\text { sputum }\end{array}$ & $\begin{array}{l}\text { Fever, cough, and } \\
\text { sore throat }\end{array}$ \\
\hline Temperature $\left({ }^{\circ} \mathrm{C}\right)$ & 39.0 & 38.0 \\
\hline White blood count $\left(\times 10^{9} / \mathrm{L}\right)$ & 3.7 & 11.3 \\
\hline Neutrophils ( $\left.\times 10^{9} / \mathrm{L}\right)$ & 2.49 & $63 \%$ \\
\hline Lymphocytes ( × 109/L) & 0.796 & $2.39^{*}$ \\
\hline Platelets ( × 109/L) & 147 & $195 *$ \\
\hline C reactive protein (mg/L) & 70 & 9 \\
\hline $\mathrm{PaCO}_{2}(\mathrm{~mm} \mathrm{Hg})$ & 26.1 & 32.5 \\
\hline $\mathrm{PaO}_{2}(\mathrm{~mm} \mathrm{Hg})$ & 135 & 92 \\
\hline $\begin{array}{l}\text { Saturation of peripheral } \\
\text { oxygen }(\%)\end{array}$ & 99.4 & $\mathrm{n} / \mathrm{a}$ \\
\hline Chest radiography & Pneumonia & Pneumonia \\
\hline Mechanical ventilation & Yes & No \\
\hline Oseltamivir treatment & Yes & Yes \\
\hline Oxygen treatment & Yes & Yes \\
\hline Outcome & Recovery & Recovery \\
\hline
\end{tabular}

n/a, not applicable. *The data on hospital admission was not applicable and showed the available data on 28 December 2015.

(PaO2) of $135 \mathrm{mmHg}$, and a carbon dioxide (PaCO2) of $26.1 \mathrm{mmHg}$ (Table 1). Routine laboratory testing revealed a white cell count (WBC) of $3.7 \times 10^{9} / \mathrm{L}$ with $59.8 \%$ neutrophils and $70 \mathrm{mg} / \mathrm{L} \mathrm{C}$ reactive protein (CRP; Table 1). Computed tomography (CT) of the chest showed left upper lobe pneumonia, lower lobe interstitial fibrosis, lower lobe predominant emphysema, and mediastinal lymph nodes (Figure 1A). On the following day, the patient developed high fever $\left(40.1^{\circ} \mathrm{C}\right)$ with cough and expectoration sputum. He was prescribed with ceftriaxone tazobactam and levofloxacin after his hospital admission. When these antibiotics turned out ineffective, he was then treated with imipenem cilastatin, vancomycin, and meropenem. However, due to the poor treatment effectiveness of these medicine and continuous deterioration of the disease condition, he was sent to the intensive care unit on May 7, and given oxygen nasal cannula and mechanical ventilation successively as well as oseltamivir $75 \mathrm{mg}$ twice daily. On May 14 , his nasal and throat samples were collected and were tested positive for H7N9 virus using real time reverse transcription PCR (rRT-PCR). After the confirmative diagnosis, he continued

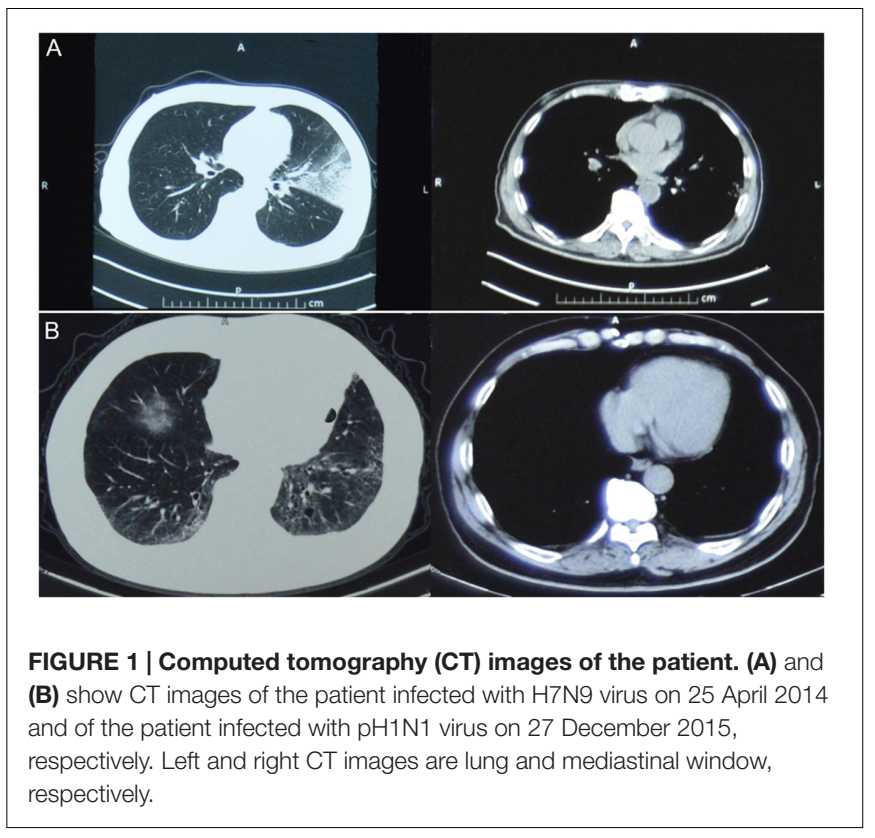

to receive oseltamivir $75 \mathrm{mg}$ twice daily with imipenem and moxifloxacin to help alleviate symptoms during May 15-26. On August 22, he recovered from the disease and was discharged from the hospital. Figure 2 summarizes the timeline of the events mentioned above.

On December 25, 2015, 1 year and 3 months after his infection with the avian influenza $\mathrm{A}(\mathrm{H} 7 \mathrm{~N} 9)$ virus, he presented ILI symptoms again, with fever $\left(38^{\circ} \mathrm{C}\right)$, cough, and sore throat. On December 27, he was admitted to the same city level hospital and was diagnosed of severe pneumonia. On admission, the patient had a temperature of $36.3^{\circ} \mathrm{C}$, a pulse of 77 beats per minute, a blood pressure of $120 / 70 \mathrm{mmHg}$, a respirations rate of 20 breaths per minute, a $\mathrm{PaO} 2$ of $92 \mathrm{mmHg}$, and a $\mathrm{PaCO} 2$ of $32.5 \mathrm{mmHg}$ (Table 1). Routine blood testing identified a WBC of $11.3 \times 10^{9} / \mathrm{L}$ with $63 \%$ neutrophils and $9 \mathrm{mg} / \mathrm{L}$ CRP (Table 1). CT of the chest showed pulmonary interstitial fibrosis with infection (Figure 1B). He was prescribed with cefotiam, xiyanping (Chinese medicine for anti-virus infection), doxofylline, and ambroxol as well as given oxygen nasal cannula. On December 29, 2015, the local municipal Center for Disease Control and Prevention was notified of the patient with severe pneumonia. Because of his historical infection with avian influenza $\mathrm{A}(\mathrm{H} 7 \mathrm{~N} 9)$ virus, an epidemiological investigation was immediately conducted on December 30, and two throat samples were collected and tested for avian influenza virus subtypes (H7N9, H5N1, and H9N2) and human seasonal influenza viruses (pH1N1 and seasonal $\mathrm{H} 1$ and $\mathrm{H} 3$ ) using rRT-PCR. Both samples were positive for influenza A virus $(\mathrm{Ct}=32.36)$ and $\mathrm{pH} 1 \mathrm{~N} 1$ virus (Ct values are 31.15 for $\mathrm{H} 1$ and 32.35 for $\mathrm{N} 1$ ), but negative for H7N9 or other subtypes of influenza virus. After the confirmation of $\mathrm{pH} 1 \mathrm{~N} 1$ virus infection, his treatment with prescribed drugs continued. On January 4, 2016, he recovered from the disease and was discharged from the hospital (Figure 2). 


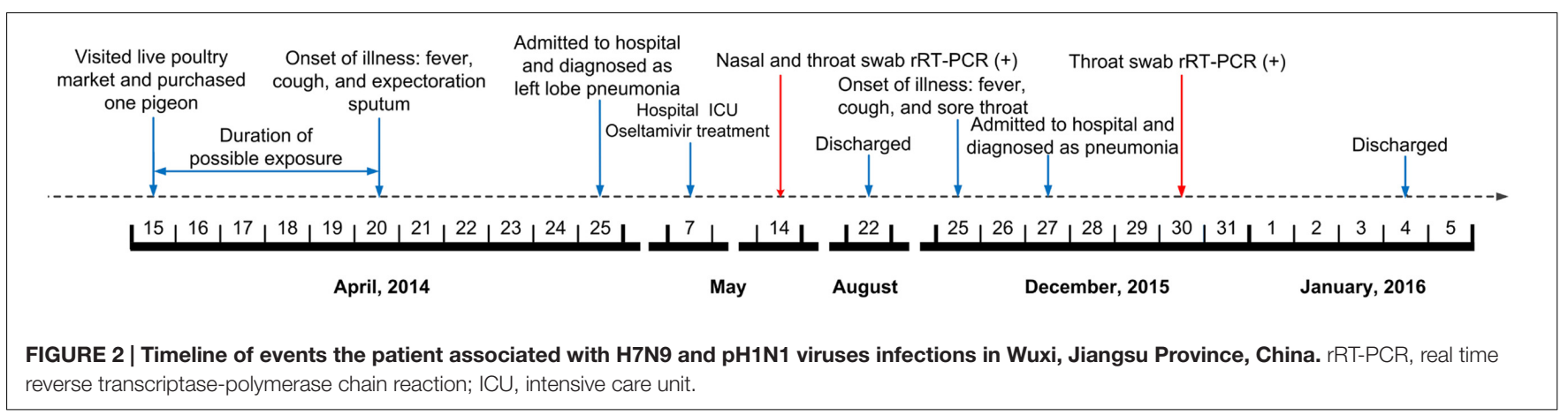

\section{HEMAGGLUTINATION INHIBITION ASSAY}

The serum hemagglutination inhibition (HAI) antibodies against the H7N9 and pH1N1 were measured as previously described (World Health Organization, 2013). The HAI titers against the H7N9 virus (A/Jiangsu/Wuxi/04/2013) were 1:40 and 1:1280 in serum samples collected on May 15 and June 16 of 2014, respectively. The HAI titer against the $\mathrm{pH} 1 \mathrm{~N} 1$ virus (A/California/07/2009) was 1:1280 in the convalescent serum samples collected on January 25, 2016. To determine whether the patient had HAI antibodies against the H7N9 virus more than 1 year after his recovery, we tested the convalescent serum for H7N9 virus and found the patient had a low HAI titer of $1: 10$.

\section{DISCUSSION}

To our knowledge, this is the first report of a survivor of the avian influenza H7N9 infection who were infected with the human influenza $\mathrm{pH} 1 \mathrm{~N} 1$ virus after his recovery from the disease. A previous study found that H7N9-infected patients had rapidly developed robust antibody responses in 10-14 days after symptom onset (Zhang et al., 2013). Our result also showed a rapidly elicited robust antibody response after the infection, but the antibody response became very weak against H7N9 virus more than 1 year later. Whether the protective antibody response decay substantially after 1 year or so in general need further investigation in more survivors, and there is likely heterogeneity across the population. Several studies have shown that memory $\mathrm{T}$ cells and broadly neutralizing antibodies induced by human seasonal influenza viruses may provide some cross-protection against the avian H7N9 virus (van de Sandt et al., 2014; Henry Dunand et al., 2015; Richards et al., 2015). It is yet unclear whether previous exposure to the avian H7N9 virus cross-protects against human seasonal influenza viruses. Severe infection with avian influenza viruses are known to be associated with delayed immune recovery and impaired lung function (Chen et al., 2016). These consequences may not have increased the susceptibility of the patients who recovered from H7N9 to seasonal influenza infection if subsequent infection occur. It is well known that most people who get influenza will have mild illness and will recover in a few days to less than 2 weeks. However, some people, including young children, adults aged 65 years and older, pregnant women, and people with chronic medical conditions, are among those groups of people who are at higher risk of serious influenza complications (Rothberg et al., 2008). For example, people with chronic lung disease are at higher risk of developing severe pneumonia. Because of severe H7N9 virus infection, the patient had a sequelae of pulmonary interstitial fibrosis although his recovery from the infection. The patient developed severe pneumonia with pH1N1 virus infection, suggesting that a survivor who has recovered from severe H7N9 virus infection may be at a higher risk of having severe complications after subsequent infection with influenza. Therefore, it may be beneficial to include previous H7N9 virus infected patients in the high-risk populations recommended to receive human seasonal influenza vaccination.

\section{INFORMED CONSENT STATEMENT}

The study complied with the Declaration of Helsinki and was approved by the Institutional Review Board of Wuxi Center for Disease Control and Prevention. The written informed consent was obtained from the study patient.

\section{AUTHOR CONTRIBUTIONS}

S-HC, M-NW, Y-HQ, G-LW, G-YM, TZ, and BL conducted the epidemiological investigation, sample, and data collection. M-NW, G-LW, and M-JM performed experiments. M-JM and $\mathrm{W}$-CC conceived and designed the study. M-JM, W-CC, and YY contributed to the writing of the manuscript.

\section{ACKNOWLEDGMENTS}

This work was supported by the grants from the Program of International Science and Technology Cooperation of China (2013DFA30800), the National Natural Science Foundation of China (81402730), the Program of Science and Technology of Jiangsu Province (H201448), and the Major Project of Wuxi Health Bureau (Z201404). 


\section{REFERENCES}

Chen, J., Cui, G., Lu, C., Ding, Y., Gao, H., Zhu, Y., et al. (2016). Severe Infection with avian Influenza A virus is associated with delayed immune recovery in survivors. Medicine (Baltimore) 95:e2606. doi: 10.1097/MD.00000000000 02606

Henry Dunand, C. J., Leon, P. E., Kaur, K., Tan, G. S., Zheng, N. Y., Andrews, S., et al. (2015). Preexisting human antibodies neutralize recently emerged H7N9 influenza strains. J. Clin. Invest. 125, 1255-1268. doi: 10.1172/JCI74374

Li, J., Kou, Y., Yu, X., Sun, Y., Zhou, Y., Pu, X., et al. (2014). Human coinfection with avian and seasonal influenza viruses, China. Emerg. Infect. Dis. 20, 1953-1955. doi: 10.3201/eid2011.140897

Richards, K. A., Nayak, J., Chaves, F. A., Dipiazza, A., Knowlden, Z. A., Alam, S., et al. (2015). Seasonal influenza can poise hosts for CD4 T-cell immunity to H7N9 avian influenza. J. Infect. Dis. 212, 86-94. doi: 10.1093/infdis/jiu662

Rothberg, M. B., Haessler, S. D., and Brown, R. B. (2008). Complications of viral influenza. Am. J. Med. 121, 258-264. doi: 10.1016/j.amjmed.2007.10.040

van de Sandt, C. E., Kreijtz, J. H., De Mutsert, G., Geelhoed-Mieras, M. M., Hillaire, M. L., Vogelzang-Van Trierum, S. E., et al. (2014). Human cytotoxic T lymphocytes directed to seasonal influenza a viruses cross-react with the newly emerging H7N9 virus. J. Virol. 88, 1684-1693. doi: 10.1128/JVI.02843-13

World Health Organization (2013). Serological Detection of Avian Influenza A(H7N9) Virus Infections by Modified Horse Red Blood Cells Haemagglutination-Inhibition Assay [Online]. Beijing: WHO Collaborating
Center for Reference and Research on Influenza at the Chinese National Influenza Center.

Zhang, A., Huang, Y., Tian, D., Lau, E. H., Wan, Y., Liu, X., et al. (2013). Kinetics of serological responses in influenza $A(\mathrm{H} 7 \mathrm{~N} 9)$-infected patients correlate with clinical outcome in China, 2013. Euro. Surveill. 18:20657. doi: 10.2807/15607917.ES2013.18.50.20657

Zhang, W., Zhu, D., Tian, D., Xu, L., Zhu, Z., Teng, Z., et al. (2015). Co-infection with Avian (H7N9) and Pandemic (H1N1) 2009 Influenza viruses, China. Emerg. Infect. Dis. 21, 715-718. doi: 10.3201/eid2104.141560

Zhu, Y., Qi, X., Cui, L., Zhou, M., and Wang, H. (2013). Human co-infection with novel avian influenza A H7N9 and influenza A H3N2 viruses in Jiangsu province, China. Lancet 381:2134. doi: 10.1016/S0140-6736(13)61135-6

Conflict of Interest Statement: The authors declare that the research was conducted in the absence of any commercial or financial relationships that could be construed as a potential conflict of interest.

Copyright (c) 2016 Chen, Wu, Qian, Ma, Wang, Yang, Zhao, Lu, Ma and Cao. This is an open-access article distributed under the terms of the Creative Commons Attribution License (CC BY). The use, distribution or reproduction in other forums is permitted, provided the original author(s) or licensor are credited and that the original publication in this journal is cited, in accordance with accepted academic practice. No use, distribution or reproduction is permitted which does not comply with these terms. 